\title{
POLA ASUH IBU DENGAN KEJADIAN STUNTING PADA ANAK USIA 24-59 BULAN DI WILAYAH KERJA PUSKESMAS KELURAHAN SEKUPANG KOTA BATAM
}

\author{
Mastiur Lumban Tobing ${ }^{1}$, Masdalina Pane ${ }^{2}$, Ester Harianja ${ }^{3}$, \\ Magister Kesehatan Masyarakat, Direktorat Pascasarjana ${ }^{1}$ \\ Universitas Sari Mutiara Indonesia ${ }^{2,3}$ \\ chelseavictoria58@gmail.com ${ }^{1}$, mastiurlumbantobing@gmail.com ${ }^{2}$
}

\begin{abstract}
Stunting is a form of stunted growth process, and is a nutritional problem that needs serious attention. Lack of parenting style, especially in giving food to children, is one of the causes of stunting. This study aims to determine the mother's parenting style with the incidence of stunting in children aged 24-59 months in the work area of the Puskesmas, Kelurahan Sekupang, Batam City in 2020. This type of research is qualitative with the case study method. The research informants were 7 people consisting of 5 mothers who have children aged 24-59 months who are stunted, 1 nutrition officer and 1 posyandu officer in the working area of Puskesmas Sekupang. This study used the interview method and measured the body length of children who had been identified as having stunted. Then the data is processed using qualitative data analysis. The results showed that the mother's upbringing was based on the care of giving food, the majority of mothers did not provide exclusive breastfeeding, the children had been given food and drink under the age of 6 months, the mothers provided breakfast but the children had difficulty eating and preferred snacks in stalls, the majority of mothers prepared food. children and the majority of mothers gave only rice porridge. Parenting is based on basic child care care that the majority of mothers work so that the child is the husband or other family member, basic immunization for children before the age of 1 year is incomplete. The mother's parenting style is based on hygiene and sanitation that the majority of mothers keep food in a closed and clean place in the cupboard, the children bathe twice a day, the children cut their nails once a week, the children's clothes are changed if they are dirty, the mothers clean the inside and outside of the house and use gallon water. refill to meet the family's drinking water needs. It is recommended to parents, especially mothers who have children with stunting, to pay more attention to parenting, especially the pattern of feeding according to a balanced nutrition menu and complete immunization for children.
\end{abstract}

Keywords $\quad$ : Maternal Parenting Style, Stunting, Children aged 24-59 months

\begin{abstract}
ABSTRAK
Stunting merupakan bentuk dari proses pertumbuhan yang terhambat, dan merupakan salah satu masalah gizi yang perlu mendapat perhatian serius. Pola asuh ibu yang kurang khususnya dalam pemberian asupan makanan pada anak merupakan salah satu penyebab terjadinya stunting. Penelitian ini bertujuan untuk mengetahui pola asuh ibu dengan kejadian stunting pada anak usia 24-59 bulan di wilayah kerja Puskesmas Kelurahan Sekupang Kota Batam Tahun 2020. Jenis penelitian kualitatif dengan metode studi kasus. Informan penelitian berjumlah 7 orang yang terdiri dari 5 orang ibu yang mempunyai anak usia 24-59 bulan yang mengalami stunting, 1 orang petugas gizi dan 1 orang petugas posyandu di wilayah kerja Puskesmas Sekupang. Penelitian ini menggunakan metode wawancara dan melakukan pengukuran panjang badan pada anak yang sudah teridentifikasi mengalami stunting. Kemudian datanya diolah menggunakan analisa data kualitatif. Hasil penelitian diperoleh bahwa pola asuh ibu berdasarkan asuhan pemberian makanan, mayoritas ibu tidak memberikan ASI ekslusif, anak sudah diberikan makan dan minum di bawah umur 6 bulan, ibu memberikan sarapan pagi tetapi anak sulit makan dan lebih memilih jajan di warung, mayoritas ibu menyiapkan makanan anak dan mayoritas ibu memberikan hanya bubur nasi saja. Pola asuh berdasarkan asuhan perawatan dasar anak bahwa mayoritas ibu bekerja sehingga yang mengasuh anak adalah suami atau anggota keluarga lainnya, imunisasi dasar pada anak sebelum usia 1 tahun tidak lengkap. Pola asuh ibu berdasarkan asuhan hygiene dan sanitasi bahwa mayoritas ibu menyimpan makanan di tempat tertutup dan bersih dalam lemari, anak mandi dua kali sehari, anak potong kuku seminggu sekali, baju anak diganti
\end{abstract}


apabila kotor, ibu membersihkan bagian dalam dan luar rumah serta menggunakan air galon isi ulang untuk memenuhi kebutuhan air minum keluarga. Disarankan kepada orang tua terutama para ibu yang mempunyai anak dengan kejadian stunting supaya lebih memperhatikan pola asuh anak khususnya pola pemberian makanan sesuai menu gizi seimbang dan imunisasi lengkap pada anak.

Kata Kunci : $\quad$ Pola Asuh Ibu, Stunting, Anak Usia 24-59 Bulan

\section{PENDAHULUAN}

Stunting merupakan bentuk dari proses pertumbuhan yang terhambat, dan merupakan salah satu masalah gizi yang perlu mendapat perhatian. Stunting menjadi permasalahan karena berhubungan dengan meningkatnya risiko terjadinya kesakitan dan kematian, perkembangan otak suboptimal sehingga perkembangan motorik terlambat dan terhambatnya pertumbuhan mental (Yesi, 2019).

Dalam Global Nutrition Targets 2025 stunting merupakan insiden yang terjadi secara global, diperkirakan sekitar 171 juta sampai 314 juta anak berusia di bawah lima tahun mengalami stunting dan $90 \%$ diantaranya berada di negara-negara Benua Afrika dan Asia. Global Nutrition Report menunjukkan Indonesia termasuk dalam 17 negara di antara 117 negara, yang mempunyai tiga masalah gizi yaitu stunting, wasting dan overweight pada balita (Venny, 2018).

Sustainable Development Goals (SDGs) menyatakan bahwa segala bentuk malnutrisi akan diselesaikan pada tahun 2030, termasuk mencapai target internasional 2025 untuk menurunkan stunting dan wasting pada balita (Nova, 2020). Menurut World Health Organization (WHO) tahun 2017, prevalensi stunting di dunia sekitar 150,8 juta balita, dan lebih dari dua juta anak di bawah umur 5 tahun meninggal dunia karena stunting yang banyak disebabkan oleh praktik pemberian makan yang buruk dan terjadinya infeksi berulang. Indonesia menempati peringkat ketiga dengan negara prevalensi stunting tertinggi di Asia Tenggara setelah Timor Leste dan India yaitu 29,6\% pada tahun 2017 (Buletin Stunting, 2018).
Kejadian stunting perlu pola asuh yang baik dengan membutuhkan peranan dari keluarga atau tenaga kesehatan dan pemerintah. Tenaga kesehatan harus melakukan penyuluhan atau memberi pengetahuan tentang pola asuh ibu supaya anaknya tidak mengalami stunting dan pengetahuan tentang tumbuh kembang anak. Faktor yang mempengaruhi terjadinya stunting salah satunya adalah kurangnya pemberian makanan yang bergizi pada anak balita dan masyarakat juga biasanya mentabukan makanan yang mengandung banyak zat gizi yang baik bagi tumbuh kembang anak (Zian, 2018).

Praktik pengasuhan yang dilakukan di dalam rumah tangga dan diwujudkan dengan tersedianya pangan dan perawatan kesehatan serta sumber lainnya untuk kelangsungan hidup, pertumbuhan, dan perkembangan anak. Aspek-aspek yang dinilai dalam penelitian ini meliputi tiga aspek yaitu praktik pemberian makan, praktik kebersihan diri dan lingkungan, serta pemanfaatan pelayanan kesehatan. Pola asuh memiliki peran dalam kejadian stunting pada balita karena asupan makanan pada balita sepenuhnya diatur oleh ibunya. Ibu dengan pola asuh baik akan cenderung memiliki balita dengan status gizi yang lebih baik dari pada ibu dengan pola asuh yang kurang baik (Venny, 2018).

Kelurahan Sekupang Kota Batam merupakan kelurahan yang berada di wilayah kerja Puskesmas Sekupang Kota Batam. Sebagian besar masyarakat yang ada di Kelurahan Sekupang adalah masyarakat dengan tingkat ekonomi menengah ke bawah. Mayoritas pekerjaan adalah pemulung dan pekerja pabrik.

Prevalensi stunting di Puskesmas Kelurahan Sekupang Kota Batam Pada 
tahun 2020 sebesar 23,5\% dari jumlah populasi yang ada. Pada tahun 2018, penderita stunting Kota Batam dengan prevalensi hanya $1,35 \%$ sedangkan tahun 2019 penderita stunting mengalami peningkatan yaitu $5,61 \%$. Penyebab utamanya adalah kurangnya asupan nutrisi pada anak usia 0 hingga 12 bulan (Puskesmas Sekupang Kota Batam, 2020).

Puskesmas Sekupang Kota Batam telah melakukan penanganan pada anak usia 2459 bulan yang mengalami stunting. Berbagai upaya penaganan telah dilakukan Puskesmas Sekupang tetapi masih kurang berhasil karena kurangnya dukungan pola asuh ibu. Gizi buruk dapat terjadi pada anak manapun yang tidak secara mutlak dipengaruhi oleh kemampuan ekonomi keluarga. Hal ini mengindikasikan bahwa anak yang berasal dari keluarga dengan kemampuan ekonomi tinggi juga dapat mengalami gizi buruk sebaliknya pada keluarga dengan perekonomian rendah masih dapat dijumpai anak dengan status gizi yang baik. Penelitian ini bertujuan untuk mengetahui Pola Asuh Ibu Dengan Kejadian Stunting Pada Anak Usia 24 - 59 Bulan di Puskesmas Kelurahan Sekupang Kota Batam.

\section{METODE}

Jenis penelitian ini adalah penelitian kualitatif dengan metode studi kasus. Lokasi penelitian dilakukan di wilayah kerja Puskesmas Kelurahan Sekupang Kota Batam. Waktu penelitian dilakukan pada Februari-Oktober 2020. Informan penelitian ini berjumlah 7 orang yang terdiri dari 5 orang ibu yang mempunyai anak usia 24-59 bulan yang mengalami stunting dengan status gizi kurang di wilayah kerja Puskesmas Sekupang, 1 orang petugas gizi dan 1 orang petugas posyandu di Puskesmas Kelurahan Sekupang Kota Batam. Dilakukan penelitian pada anak usia 24-59 bulan karena pada usia ini pola asuh ibu masih mempunya peran yang sangat penting dalam tumbuh kembang anak. Dengan pola asuh yang baik maka dapat menurunkan angka stunting pada anak.

Instrumen yang digunakan dalam penelitian ini adalah kuesioner untuk membantu peneliti dalam mengumpulkan data dengan cara wawancara untuk mengumpulkan data, alat perekam untuk merekam, meteran untuk melakukan pengukuran dan kamera untuk dokumentasi. Analisa data mengunakan analisa kualitatif hasil wawancara yang dilakukan kepada ibu responden. Adapun pola asuh yang diteliti berupa kebiasaan pemberian ASI Eksklusif dan pemberian Makanan Tambahan/PMT ASI, kebiasaan pengasuhan, kebiasaan kebersihan dan kebiasaan mendapatkan pelayanan Kesehatan.

\section{HASIL}

\section{Asuhan Pemberian Makan}

Pada penelitian ini yang menjadi informan yakni Ibu yang mempunyai anak usia 24-59 bulan yang mengalami stunting, ada beberapa pertanyaan yakni terkait pemberian ASI Eksklusif, pemberian makanan tambahan/ PMT-ASI, sarapan pagi, makanan anak, menyiapkan makan dan suasana makan, berikut hasil wawancaranya:

\section{Pemberian ASI Eksklusif}

Berdasarkan hasil wawancara mengenai pemberian ASI Eksklusif didapatkan hasil bahwa mayoritas ibu tidak memberikan ASI Eksklusif pada anaknya.

Hasil wawancara dijelaskan sebagai berikut:"ibu A mengemukakan alasannya mengapa tidak memberikan ASI Eksklusif, karena ibu A bekerja di pabrik sehingga ia harus masuk bekerja, diberikan cuti hanya 3 bulan sehingga dari umur 4 bulan sudah diberikan susu formula".Ibu B juga menjelaskan bahwa "Saya berikan lho ASI saja sampai anak umur 6 bulan. Baru dari 6 bulan itu anak saya ditambah dengan susu formula dan makanan". Dan Ibu C juga menjelaskan "Inilah yang sulit. Saya ingin memberikan ASI sampai 6 bulan tapi 
ya bagaimanalah...saya juga harus bekerja untuk mencukupi kebutuhan ekonomi keluarga" Ibu D juga memaparkan bahwa "Saya berikan ASI tapi ASI saya sedikit sehingga dibantu susu formula. Susu formula yang saya berikan susu encer yang dalam kemasan. Bagaimanalah saya tidak mampu membeli susu mahal". Ibu E menjelaskan bahwa "Saya berikan dong ASI saja sejak lahir sampai umur 6 bulan. Itulah, untunglah ASI saya ada sehingga saya tidak membeli susu lagi. Beli susu harganya mahal"

Dari hasil wawancara didapatkan bahwa mayoritas responden memberikan ASI kepada anaknya hanya sampai usia 6 Bulan saja dan setelah itu anak diberikan susu formula ataupun makanan pendamping tanpa diberikan ASI lagi.

\section{Pemberian Makanan Tambahan/ PMT- ASI}

Berdasarkan hasil wawancara mengenai Pemberian Makanan Tambahan/ PMT-ASI, mayoritas anak yang mengalami stunting diberikan makan minum di bawah umur 6 bulan dikarenakan ibu merasa ASI tidak cukup untuk anak dan ibu sibuk bekerja.

Hasil wawancara dijelaskan sebagai berikut : pada Ibu A menjelaskan "Anak saya mendapatkan makanan dan minuman sejak umur 4 bulan. Saya bekerja sehingga anak saya nangis terus. Apalah yang dibuat. Pada saat itu langsung diberikan makanan tambahan". Ibu B juga menjelaskan "Saya memberikan makan saya sejak 6 bulang dong. Saya kan memberikan ASI ekskusif. Itupun anak susah makan. Itu mau netek saja".Ibu C juga menjelaskan bagaimana ia memberikan makanan tambahan pada anaknya"Seingat saya ya.. Saya memberikan makan sejak usia 3 bulan. Saya bekerja jadi saya anggap susu tidak cukup. Terus saya lihat berat badan anak saya kurus. Saya langsung berikan makan". Ibu D memaparkan penjelasannya "Anak saya kan saya berikan ASI sampai 2 bulan. ASI saya sedikit bu. Jadi saya berikan makanan encer. Itupun sulit lho anak saya makannya. Itupun saya berikan makan tapi berat badan anak saya tidak naik". Ibu E juga menjelaskan "ltulah saya berikan ASI ekslusif sampai anak umur 6 bulan terus disitu saya berikan makan. Tapi berat badan anak tidak naik. Sulit lho anak saya makan bu. Saya memang memberikan makanan apa adanya karena bagaimanalah keuangan saya tidak cukup"

\section{Sarapan Pagi}

Berdasarkan hasil wawancara mengenai sarapan pagi yang dimakan oleh anak usia 24-59 Bulan, mayoritas informan ibu memberikan anak sarapan pagi tetapi anak sulit makan dikarenakan selera makan anak yang kurang.

Hasil wawancara dijelaskan sebagai berikut: ibu A menjelaskan "Saya berikan makan pagi tapi anak sulit makan. Diberikan makan pagipun tapi berat badan anak saya tidak naik". Ibu B juga menjelaskan "Sarapan pagi tetap diberikan tapi makannya dikit bu. Anak saya sulit makan lho bu". Ibu C memaparkan penjelasannya "Tetap bu diberikan sarapan pagi walaupun dikit dimakan anak saya bu. Kesulitan saya memberikan anak saya makan bu". Ibu D juga menjelaskan "Saya berikan makan anak setiap pagi tapi ya gimanalah anak saya memang sulit sarapan pagi bu. Ini lah berat badannya sulit naik. Begini aja terus bu". Ibu E memaparkan jawabannya "Saya biasakan lho bu anak saya sarapan pagi tapi itu sedikit aja yang dia makan. Makan harus dipaksa walau sedikit aja yang dia makan $b u$ "

\section{Makanan Anak}

Berdasarkan hasil wawancara mengenai makanan anak, mayoritas ibu memberikan anak makan hanya bubur nasi saja dikarenakan kondisi ekonomi keluarga. Mayoritas anak sulit diberikan makan sehingga berat badan anak turun dan tidak bertambah.

Hasil wawancara dijelaskan sebagai berikut. Ibu A menjelaskan "Saya 
memberikan makanan anak saya hanya bubur nasi saja bu...Pernah bu saya berikan indomie atau ayam krispi yang dijual tapi hanya sedikit anak saya mau memakannya. Pada dasarnya anak saya memang sulit untuk makan. Mungkin itulah bu yang menyebabkan berat badan anak saya sulit naik".

Ibu B juga menjelaskan "Anak saya sulit makan bu jadi kalau saya siapkan makanan yang sehat lengkap dengan ikan dan sayur itu hanya beberapa sendok aja yang dimakan anak. Jadi terkadang terbuang makanan yang saya berikan ke anak saya bu. Mungkin inilah yang buat berat badan anak saya sulit naik".

Ibu $\mathrm{C}$ juga memaparkan penjelasannya "Saya berikan anak saya makan bu tapi ya hanya sedikit yang dimakan anak. Sulit anak saya diberikan makan. Segala upaya sudah saya usahakan. Tapi ya memang anak saya sulit makan bu. Anak saya tidak suka makan sayur jadi supaya mau makan, pernah saya berikan indomie kepada anak"

Hasil wawancara dengan ibu D "Cara saya berikan anak saya makan seperti ibu yang lain bu. Tapi memang karena faktor ekonomi saya berikan makan ya makanan sederhana aja yang bisa bu. Saya biasanya berikan bubur nasi. Itupun sulit anak saya makan hanya sedikit yang dimakan anak saya bu". Dan hasil wawancara dengan ibu E "Saya memberikan bubur nasi tim bu. Tapi ibu kan tahu juga sekarang ada pandemik penyakit covid. Ekonomi keluarga saya menurun bu. Jadi saya hanya berikan bubur nasi saja bu".

\section{Menyiapkan Makan}

Berdasarkan hasil wawancara mengenai cara menyiapkan makan, mayoritas ibu yang menyiapkan makanan anaknya. Hasil wawancara tentang siapa menyiapkan makanan dijelaskan oleh ibu sebagai berikut:

Ibu A menjelaskan "Yang menyiapkan makan anak saya tetap saya bu. Gak ada yang bisa saya minta tolong bu. Sebelum saya berangkat kerja saya masakan anak saya makan. Tapi yang mengasih anak saya makan bukan saya karena saya bekerja bu". Ibu B menjelaskan "Sebelum pergi kerja saya masak bu, ya.. gimana bu kalau seandainya kurang terpaksa beli di warung bu". Ibu C juga memaparkan penjelasannya "Sebelum saya berangkat kerja bu. Saya harus sempatkan masak makan anak bu. Tapi ya sekedar hanya bubur nasi saja bu”. Ibu D menjelaskan "Tidak ada yang bantu saya bu. Tiap hari harus mondar mandir bu. Sesibuk apapun saya sempatkan buat bubur anak saya. Tapi yang memberikan anak saya setiap hari itu kakaknya bu. Saya bekerja di pabrik bu. Jadi saya gak sempat mengasih makan anak saya bu". Ibu E juga menjelaskan "Siapa lagi kalau bukan saya bu. Saya yang masakin makan anak saya bu. Tak ada yang bisa saya minta tolong bu. Kalau saya bekerja keluarga yang berikan anak makan. Kalau saya libur saya yang berikan makan anak saya bu".

Dari hasil wawancara didapatkan hasil yang menyiapkan makanan untuk anak mereka adalah mereka sendiri walaupun mereka sibuk mereka tetap menyempatkan waktu untuk menyiapkan makanan.

\section{Suasana Makan Anak}

Berdasarkan hasil wawancara mengenai suasana makan anak mayoritas ibu sudah membuat suasana menyenangkan saat anak makan tapi memang anak sulit makan.

Hasil wawancara tentang suasana makan anak dijelaskan oleh ibu sebagai berikut Ibu A menjelaskan "Anak saya sulit makan bu. Saya sering membujuk dan membuat suasana menyenangkan untuk anak saya supaya mau makan tapi memang anak saya sulit makan bu". Ibu B juga menjelaskan "Inilah susahnya anak saya bu. Sulit makan anak saya bu. Makanpun harus dipaksa, itupun hanya beberapa suap saja bu. Kalau di bujuk saya tidak cukup bu. Memang anak saya ini sulit makan bu. Inilah yang membuat berat badannya sulit naik bu". Ibu C juga menjelaskan "Sulit bu anak saya makan bu. Sering saya buat suasana menyenagkan tapi entah kenapa 
ya bu. Memang anak saya sulit bu untuk dikasi makan bu"

Ibu D memaparkan penjelasan "Menu makan apapun anak saya sulit makannya bu. Ini memang saya sering hanya buat bubur nasi bu. Makanpun harus dipaksa kalau buat yang makanan menarik. Saya belum sanggup bu. Ekonomi keluarga masih kurang bu”.'Ibu E juga menjelaskan "Suasana menyenangkan saat makan sering buat untuk membuat anak mau makan tapi memang anak saya sulit makan. Apapun saya buat sulit makan bu. Inilah yang membuat berat badan anak saya sulit naik bu”

\section{Informan Petugas Gizi di Puskesmas Kelurahan Sekupang Kota Batam}

Penanganan Stunting yang dilakukan tenaga kesehatan dari aspek Asuhan Pemberian Makan yang baik pada anak usia 24-59 bulan adalah: petugas gizi sudah melakukan penyuluhan tentang pemberian makanan yang baik dan bergizi pada anak, Pemberian Makan Tambahan/PMT-ASI berupa pemberian biskuit di puskesmas untuk anak yang mengalami stunting serta mengadakan kunjungan tiap bulan untuk mengetahui pertumbuhan dan pengukuran berat badan anak yang mengalami stunting tersebut.

Hasil wawancara tentang Penanganan Stunting yang dilakukan tenaga kesehatan berdasarkan Asuhan Pemberian Makan yang baik pada anak usia 24-59 bulan dijelaskan oleh petugas gizi di Puskesmas Kelurahan Sekupang Kota Batam sebagai berikut :

"Kami sebagai petugas gizi di Puskesmas Kelurahan Sekupang Kota Batam sudah melakukan upaya dalam mengatasi stunting yang terjadi di Kelurahan Sekupang Kota Batam dengan memberikan penyuluhan tentang pemberian makan yang baik dan bergizi bagi anak bukan karena mahalnya makanan tapi dari jenis zat gizi yang terkandung pada makanan tersebut sesuai dengan kebutuhan balita menurut umurnya. Pemberian Makanan
Tambahan/PMT-ASI berupa biskuit yang ada di puskesmas juga dibagikan. Saya sudah menjelaskan makan dengan menu gizi seimbang yang seharusnya dapat menaikkan berat badan anak, tetapi apa boleh buat sulit bagi 5 orang ibu yang punya anak stunting ini menerapkannya dengan alasan faktor ekonomi sehingga ibu tidak bisa memberikan menu makanan yang seharusnya anak dapatkan".

\section{Informan Petugas Posyandu di Kelurahan Sekupang Kota Batam}

Penanganan Stunting yang dilakukan petugas posyandu di Kelurahan Sekupang Kota Batam berdasarkan asuhan pemberian makan yang baik pada anak usia 24-59 bulan adalah mengajak ibu untuk membawa anaknya setiap bulan ke posyandu dan memberikan penyuluhan kepada ibu tentang asuhan pemberian makan yang baik.

Hasil wawancara berdasarkan asuhan pemberian makan yang baik pada anak usia 24-59 bulan dijelaskan oleh petugas posyandu di Kelurahan Sekupang Kota Batam sebagai berikut :

"Pada kegiatan di posyandu, kita sudah melakukan penanganan untuk mengatasi stunting pada anak usia 24-59 bulan di Kelurahan Sekupang Kota Batam dengan cara mengajak ibu untuk menimbang anak setiap bulan ke posyandu, memberikan penyuluhan kepada ibu tentang asuhan pemberian makan yang baik pada anak dalam mengatasi berat badan anak yang menurun. Ibu anak usia 24-59 bulan tersebut menjawab kesulitan memberikan makan anak dikarenakan faktor ekonomi keluarga yang kurang”.

\section{Asuhan Perawatan Dasar Anak}

Pada penelitian ini yang menjadi informan yakni Ibu yang mempunyai anak usia 24-59 bulan yang mengalami stunting, ada beberapa pertanyaan yakni mangasuh anak, pemberian imunisasi dasar, tempat 
berobat anak, pelibatan ayah dan keluarga lain dalam mengasuh anak, berikut hasil wawancaranya:

\section{Mengasuh Anak}

Mayoritas ibu menjawab yang mengasuh anaknya adalah ibu sendiri dibantu oleh suami dan anggota keluarga lain apabila ibu sedang bekerja. Pada umumnya ibu menghabiskan waktu bekerja di luar rumah lebih banyak sehingga kurang dalam melakukan perawatan dasar anak.

Hasil wawancara tentang mengasuh anak dijelaskan oleh ibu sebagai berikut :

Menurut Ibu A "Kalau saya bekerja, yang mengasuh anak dibantu suami saya bu. Kalau saya lagi libur baru saya sendiri bu. Bapaknya memberi makan tapi bagaimanalah bu kalau laki-laki yang berikan makan". Berdasarkan pemaparan ibu B "Saya yang menjaga anak saya bu, tetapi seandainya saya bekerja yang jaga kakaknya bu...Anak saya juga gak mau makan, lebih suka jajanan. Kalau saya bekerja sulit untuk memantau makan anak". Pemaparan ibu C "Saya yang mengasuh anak saya bu dan yang berikan makannya serta memandikannya juga saya..Terkadang anak saya telat makan bu, karena harus menunggu saya pulang dari kerja dulu”. Pemaparan Ibu D “Anak saya karena ini lah bu berat badannya sulit naik, yang memberikan makan tidak mau orang lain kecuali saya sendiri. Sebelum saya pergi kerja saya mandikan dan kasi makan dulu. Semua menunggu saya. Makanpun harus saya bu yang berikan setelah pulang kerja". dan pemaparan ibu E "Merawat anak saya, memandikan, membersihkan dan memberikan makan saya dibantu oleh kelurga saya. Saya tinggalnya bersama orang tua saya. Yang menjadi masalah itu anak saya sulit makan. Makannya hanya sedikit saja bu. Sudah dibujuk untuk makan tapi memang anak saya sulit makan bu”.

\section{Pemberian Imunisasi Dasar}

Berdasarkan wawancara mengenai pemberian imunisasi dasar, mayoritas pemberian imunisasi dasar pada anak sebelum usia 1 tahun tidak lengkap didapat anak dikarenakan anak sering sakit.

Hasil wawancara tentang pemberian imunisasi dasar dijelaskan oleh ibu sebagai berikut:

Menurut Ibu A "Imunisasi anak saya tidak lengkap (hanya mendapat DPT dan Polio) bu dikarenakan anak saya sering sakit, jadi petugas posyandu tidak memberikan anak imunisasi hanya di timbang berat badan saja bu". Berdasarkan pemaparan Ibu B "Anak saya ya bu... karena berat badannya kurang bu sering sakit anak saya bu jadi imunisasinya kurang lengkap (tidak dapat imunisasi campak waktu usia 9 bulan) bu". Pemaparan Ibu C "Imunisasi dasar yang ada di posyandu itu bu. Anak saya imunisasinya tidak lengkap, tidak mendapat imunisasi BCG dan campak karena anak saya sering sakit". Pemaparan Ibu D "Anak saya ini bu... kasihan saya, sering sakit dia bu.. Oleh karena itu imunisasinya tidak lengkap bu. Hanya mendapatkan BCG saja. Mungkin yang menyebabkan imunisasi anak saya kurang karena sering sakit anak saya bu". Dan pemaparan ibu E "Anak saya tidak mendapatkan imunisasi campak itu lho bu. imunisasi pada umurnya 9 bulan. Saya permisi dari kerja sulit bu sehingga saya tidak membawa anak saya imunisasi, ditambah anak saya juga sering sakit”.

\section{Tempat Anak Berobat}

Berdasarkan tempat anak berobat, mayoritas ibu membawa anak berobat ke puskesmas dikarenakan lebih dekat ke rumah.

Hasil wawancara tentang tempat anak berobat dijelaskan oleh ibu sebagai berikut

Menurut Ibu A “Anak saya sering sakit bu. Saya hanya sanggup bawa ke puskesmas. Ke puskesmas aja saya bawa kalau anak saya sakit bu". Berdasarkan pemaparan Ibu B“Saya hanya membawa ke puskesmas bu, apalagi puskesmas dekat dengan rumah saya bu. Jadi kalau anak sakit hanya ke puskesmas saja bu”. Pemaparan ibu C "Entahlah bu.. anak saya sering sakit bu. 
Saya hanya bawa ke puskesmas karena juga anak saya sering dapat makanan tambahan dari puskesmas bu". Pemaparan ibu D "Jika anak saya sakit saya hanya bawa ke puskesmas bu. Itu aja pilihan bu. Saya gak pernah bawa kemana-mana. Apalagi di puskesmas saya juga mendapat penyuluhan untuk menaikkan berat badan anak saya". Dan pemaparan ibu E "Anak saya hanya saya bawa ke puskesmas kalau sakit bu. Apalagi anak saya sering sakit, dan hanya bisa saya bawa ke puskesmas bu karena biaya pengobatannya juga lebih terjangkau di puskesmas".

\section{Melibatkan Ayah Dan Keluarga Lain Dalam Pengasuhan Dan Perawatan Dasar Anak}

Mayoritas informan menjawab melibatkan ayah dan keluarga lain dalam pengasuhan dan perawatan dasar anak. Hal ini dikarenakan ibu bekerja di luar rumah dengan waktu yang lama untuk mencukupi ekonomi keluarga.

Hasil wawancara tentang melibatkan ayah dan keluarga lain dalam pengasuhan dan perawatan dasar anak dijelaskan oleh ibu sebagai berikut :

Menurut ibu A "Saya bekerja bu. Jadi apabila saya bekerja yang menjaga anak saya itu ayahnya. Ekonomi keluarga saya kurang bu. Walaupun UMR Kota Batam lumayan tapi biaya hidup kan besar bu, jadi saya gantian aja dengan suami bu". Berdasarkan pemaparan Ibu B "Apabila saya bekerja yang menjaga anak saya itu kakaknya bu. Gak sanggup menitip anak ke orang bu, saya tidak sanggup untuk membayarnya bu". pemaparan ibu C "Kalau saya bekerja, anak saya bersama ayahnya di rumah bu. Saya dan suami bergantian menjaga anak saya bu. Pemaparan ibu D "Yang menjaga anak saya adalah suami dan kakaknya kalau saya lagi bekerja bu. Dan pemaparan ibu E "Saya melibatkan keluarga dalam menjaga dan merawat anak, saya tinggal bersama orang tua saya. Jadi apabila saya bekerja, anggota keluarga yang membantu saya dalam menjaga anak”.

\section{Mengajak Anak Bermain}

Mayoritas ibu sering mengajak anak untuk bermain, tetapi karena anak sering sakit si anak tersebut sudah tidak bersemangat lagi untuk bermain dan lebih banyak tiduran di tempat tidur saja.

Hasil wawancara tentang mengajak anak bermain dijelaskan oleh ibu sebagai berikut :

Menurut Ibu A "Saya sering mengajak anak saya bermain tapi anak saya sering lemas dikarenakan mungkin tidak mau makan ya bu..Anak saya lebih sering tiduran aja bu". Ibu B memaparkan "Kalau ada waktu saya setelah pulang kerja, saya sering membawa anak saya bermain di rumah tapi anak saya sering tidak bersemangat bu. Anak saya memang sering sakit bu. Ibu C memaparkan "Saya dan suami sering membuat suasana gembira untuk anak saya supaya anak saya mau bergerak tetapi anak saya sering sakit bu untuk bermain pun jarang dia mau. Hanya lebih banyak tiduran di tempat tidur saja”. Ibu D memaparkan "Kenapa ya bu.. karena anak saya sering lemas, anaknya susah makan. Saya sering membawa bermain tapi anak saya memang sering kurang semangat bu dan sulit diajak bermain". Dan Ibu E memaparkan "Saya tinggal bersama orang tua saya. Keluarga dan saya sering mengajak anak saya untuk bermain tetapi karena anak saya sering sakit jadi sulit sekali kalau dia diajak untuk bermain".

\section{Informan Petugas Gizi di Puskesmas Kelurahan Sekupang Kota Batam}

Penanganan stunting adalah memberikan penyuluhan kepada ibu pada saat membawa anak ke puskesmas dan petugas gizi melakukan kunjungan ke rumah-rumah.

Hasil wawancara yang lakukan sebagai petugas gizi dalam penanganan stunting berdasarkan asuhan perawatan dasar anak yang baik pada anak usia 24-59 bulan dapat dijelaskan sebagai berikut :"Asuhan perawatan dasar anak dalam penanganan 
stunting sudah diberikan kepada ibu dengan memberikan penyuluhan pada saat ibu membawa anak ke puskesmas atau saat petugas melakukan kunjungan ke rumah rumah. Kami sebagai petugas melihat ibu dari anak tersebut sudah menerapkan perawatan dasar yang dibutuhkan anak, ibu dibantu oleh anggota keluarga lain dalam merawat anak. Apabila ada masalah atau keluhan pada anak, ibunya segera membawa anak ke puskesmas untuk mengetahui kondisi si anak.”

\section{Informan Petugas Posyandu di Kelurahan Sekupang Kota Batam}

Penanganan stunting berdasarkan asuhan perawatan dasar anak yang baik pada anak usia 24-59 bulan, petugas posyandu lebih memperhatikan pertumbuhan dan perkembangan anak. Petugas posyandu selalu memperhatikan tumbuh kembang anak melalui KMS dan memantau kelengkapan imunisasi anak. Pemberian penyuluhan tentang pentingnya imunisasi lengkap pada anak supaya anak kebal tidak mudah terserang penyakit dan menganjurkan ibu untuk membawa anak ke posyandu.

Hasil wawancara tentang apakah yang anda lakukan sebagai tenaga kesehatan dalam penanganan stunting berdasarkan asuhan perawatan dasar anak yang baik pada anak usia 24-59 bulan dijelaskan oleh petugas posyandu di Kelurahan Sekupang Kota Batam sebagai berikut :"Pada saat ibu membawa anak ke posyandu setiap awal bulan, petugas posyandu memperhatikan anak yang mengalami stunting dengan memperhatikan pertumbuhan dan perkembangan anak melalui KMS dan data anak yang ada pada mereka. Petugas posyandu selalu memberikan penyuluhan tentang asuhan perawatan dasar yang dibutuhkan anak dalam penanganan stunting pada anak usia 24-59 bulan serta ibu diberikan kesempatan untuk bertanya tentang masalah-masalah yang dihadapi ibu dalam memberikan asuhan perawatan dasar pada anak."

\section{Asuhan Higiene dan Sanitasi}

\section{Penyimpanan Makanan Anak}

Mayoritas ibu menyimpan makanan di tempat tertutup dan bersih dalam lemari sehingga terjaga, bersih dan terhindari dari kotoran atau lalat sebagai penular penyakit. Berdasarkan hasil wawancara dengan informan 1,2,3,4 dan 5 mengatakan bahwa ibu menyimpan makanan di tempat bersih dan tertutup di dalam lemari sehingga terhindar dari kotoran atau lalat sebagai penular penyakit.

Hasil wawancara tentang penyimpanan makan anak dijelaskan oleh ibu sebagai berikut: Ibu A menjelaskan "Menyimpan makanan selalu di tempat tertutup dan bersih. Tapi sewaktu mengasih makan anak sulit dan lama dikasi makan sehingga makanan terbuka". Ibu B memaparkan "Saya menyimpan makanan didalam lemari tempat tertutup. Saya menjaga makanan agar lalat tidak hinggap di makanan”. Ibu C memaparkan "Walaupun keadaan rumah saya sederhana tapi saya tetap menjaga kebersihan. Menyimpan makanan saya selalu di tempat tertutup dalam lemari dan dalam keadaan bersih". Ibu D juga memaparkan "Makanan saya simpan dalam lemari tempat bersih dan tertutup. Kebersihan selalu saya jaga agar makanan terhindari dari kotoran atau lalat sebagai penular penyakit". Dan Ibu E memaparkan "Siap saya memasak saya menyimpan makanan dalam lemari di tempat tertutup. Saya selalu menjaga agar makanan bersih dan terhindari dari kotoran atau lalat sebagai penular penyakit"

\section{Memandikan Anak}

Berdasarkan hasil wawancara Mayoritas anak mandi dua kali sehari yaitu pagi dan sore.

Hasil wawancara tentang memandikan anak dijelaskan oleh ibu sebagai berikut : ibu A menjelaskan "Saya memandikan anak dua kali sehari pagi dan sore supaya anak saya nampak segar. Saya senang melihat anak saya bersih". Ibu B memaparkan "Anak 
saya sering sakit sehingga saya hanya memandikan pagi hari saja. Saya takut anak saya sakit apabila mandi sore”. Ibu C memaparkan "Saya memandikan anak dua kali lah bu... pagi dan sore. Anak saya senang kalau mandi". Ibu D memaparkan "Pastilah bu, anak saya senang main air sehingga saya memandikannya dua kali sehari yakni pagi dan sore”. Dan Ibu E memaparkan "Hobby anak saya mandi bu. Saya setiap hari memandikan anak saya pagi dan sore bu"

\section{Memotong Kuku}

Berdasarkan hasil penelitian mengenai waktu memotong kuku Mayoritas anak potong kuku seminggu sekali.

Hasil wawancara tentang memotong kuku dijelaskan oleh ibu sebagai berikut : ibu A menjelaskan "Anak saya apabila kukunya sudah agak panjang, saya langsung bu memotongnya. Anak saya suka isap jempol". Ibu B memaparkan "Biasanya bu seminggu sekali.. Apabila kuku anak saya agak panjang, saya langsung memotongnya bu”. Ibu C memaparkan "Kuman banyak bu apabila kuku anak panjang. Anak saya ini bu biasanya memang seminggu sekali potong kuku”. Ibu D memaparkan "Biasanya ayahnya yang potong kuku anak saya ini bu. Ayahnya sayang dengan anak saya. Biasanya seminggu sekali potong kuku bu...". Dan Ibu E memaparkan "Potong kuku ya bu? Anak saya seminggu sekalilah bu...kalau panjang saya langsung potong bu'.

\section{Mengganti Pakaian}

Berdasarkan hasil wawancara mengenai mengganti pakaian mayoritas ibu menganti baju anak apabila baju anak kelihatan kotor.

Hasil wawancara tentang mengganti pakaian dijelaskan oleh ibu sebagai berikut : ibu A menjelaskan "Kalau saya yang jaga anak saya bu, seandainya bajunya kotor langsung saya ganti". Ibu B memaparkan "Anak saya kalau bajunya kotor pasti saya ganti bu. Biasanya satu hari bisa tiga kali ganti baju bu. Anak bersih kan senang kita melihatnya bu" Ibu C memaparkan
"Biasanya ya bu... kalau bajunya kotor langsung saya ganti bu karena ayahnya juga tidak suka lihat anaknya kotor bu”. Ibu D memaparkan "Saya gantilah bu, kalau bajunya kotor ya langsung saya ganti bu". Dan Ibu E memaparkan "Wah.. jangankan saya. Ayahnya juga tidak suka lihat anaknya memakai baju yang kotor, langsung mereka ganti bu”.

\section{Membersihkan Rumah}

Berdasarkan hasil wawancara mengenai membersihkan rumah, Mayoritas ibu membersihkan bagian dalam dan luar rumah agar lalat tidak berkembang biak. Biasanya ibu membersihkan rumah apabila pulang bekerja.

Hasil wawancara tentang membersihkan rumah dijelaskan oleh ibu sebagai berikut: Ibu A menjelaskan"Saya memang bekerja bu, tetapi semampu saya pasti saya bersihkan rumah juga bu. Saya dibantu suami membersihkan rumah bagian dalam dan luar rumah". Ibu B memaparkan "Saya membersihkan rumah bagian dalam dan luar bu...Yang namanya anak pasti buat kotor, tetapi semampu saya pasti saya bersihkan". Ibu C memaparkan "Pastilah bu dibersihkan. Dalam dan luar rumah kalau kotor pasti dibersihkan. Bersih itu enak dipandang dan lalat tidak berkembang biak dalam rumah bu". Ibu D memaparkan "Biasanya pulang bekerja, saya bersihkan rumah bu... tetapi kalau untuk membersihkan luar rumah saya seminggu sekali bu". Dan Ibu E memaparkan "Membersihkan rumah pasti bu. Saya usahakan semampu saya untuk membersihkan bagian dalam dan luar rumah pulang bekerja agar lalat tidak masuk dan berkembang biak”.

\section{Kebersihan Lingkungan}

Berdasarkan hasil wawancara mengenai kebersihan lingkungan rumah Mayoritas informan menjaga kebersihan lingkungan. Sebagian ibu memakai air galon dalam memenuhi kebutuhan air minum keluarga. 
Hasil wawancara tentang kebersihan lingkungan dijelaskan oleh ibu sebagai berikut : ibu A menjelaskan "Kami orang susah dalam ekonomi bu. Saya akui kebersihan lingkungan rumah kurang bu. Mungkin inilah penyebab anak saya sering diare ditambah lagi anak saya sering tidak mau makan bu”. Ibu B memaparkan "Anak saya sulit makan bu dan sering diare. Air minum yang kami konsumsi pakai air galon isi ulang bu. Ekonomi keluarga kami kurang bu. Kebersihan rumah juga ya begini aja lah bu, apa adanya... Ibu C memaparkan "Kebersihan lingkungan ya begini lah bu...Seupayanya saya aja usahakan bersih bu. Tapi karena saya bekerja tidak ada yang bantu jadi seadanya aja. Air minum yang kami minum itu air galon isi ulang aja bu”. Ibu D memaparkan "Lingkungan rumah ya apa adanya bu. Kebersihan makan dan minum semampu saya buat bersih. Itu memang saya jaga bu." Dan Ibu D memaparkan "Saya tinggal bersama keluarga bu. Jadi keluarga membantu saya dalam membersihkan rumah walaupun tempat tinggal kami sederhana bu tetapi kalau untuk kebersihan selalu terjaga.'

\section{Informan Petugas Gizi di Puskesmas Kelurahan Sekupang Kota Batam}

Penanganan stunting oleh petugas gizi Puskesmas Sekupang Kota Batam berdasarkan asuhan hygiene dan sanitasi yang baik pada anak usia 24-59 bulan yaitu memberikan punyuluhan tentang hygiene dan sanitasi yang baik.

Hasil wawancara yang dilakukan sebagai petugas gizi dalam penanganan stunting berdasarkan asuhan hygiene dan sanitasi yang baik pada anak usia 24-59 bulan dijelaskan oleh petugas gizi di Puskesmas Kelurahan Sekupang Kota Batam sebagai berikut :

"Penyuluhan tentang hygiene dan sanitasi yang baik selalu kami berikan sebagai petugas gizi. Di saat kami kunjungan rumah, kami menegur dan mengingatkan ibu-ibu yang tidak mengganti baju anak apabila kotor. Kami juga menegur apabila kuku anak panjang dan menganjurkan ibu untuk memotong kuku anak tersebut. Mayoritas ibu yang punya balita yang mengalami stunting ini sudah menyimpan makanan di tempat yang bersih di dalam lemari."

\section{Informan Petugas Posyandu di Kelurahan Sekupang Kota Batam}

Penanganan stunting yang dilakukan oleh petugas posyandu berdasarkan asuhan hygiene dan sanitasi pada anak usia $24-59$ bulan adala Penyuluhan tentang personal hygiene dan kebersihan lingkungan baik di dalam maupun di luar rumah.

Hasil wawancara tentang apakah apa yang anda lakukan sebagai tenaga kesehatan dalam penanganan stunting berdasarkan asuhan hygiene dan sanitasi yang baik pada anak usia 24-59 bulan dijelaskan oleh petugas posyandu sebagai berikut :

"Penyuluhan sewaktu posyandu selalu ada tentang asuhan hygiene dan sanitasi yang baik dan dari kegiatan posyandu juga petugas kesehatan melakukan kunjungan rumah. Biasanya kunjungan rumah dilakukan sehabis posyandu".

\section{PEMBAHASAN}

\section{Pola Asuh Ibu Berdasarkan Asuhan Pemberian Makan Dengan Kejadian Stunting Pada Anak Usia 24-59 Bulan}

Mayoritas ibu yang mempunyai anak usia 24-59 bulan yang mengalami stunting tidak memberikan ASI Eksklusif, anak diberikan makan minum atau yang disebut dengan istilah PMT-ASI di bawah umur 6 bulan, ibu memberikan anak sarapan pagi tetapi anak sulit makan dikarenakan selera makan anak yang kurang dan lebih suka jajan, ibu memberikan anak makan hanya bubur nasi saja dikarenakan kondisi ekonomi yang kurang, ibu menyiapkan makan anak serta membuat suasana 
menyenangkan saat anak makan, tetapi anak memang sulit untuk makan.

Penelitian Rahmayana mengatakan bahwa asuhan pemberian makanan pada anak merupakan bagian dari pola asuh yang mempengaruhi kejadian stunting pada anak usia 24-59 bulan. Ibu yang memberikan ASI eksklusif pada anak, PMT-ASI yang diberikan mulai dari 6 bulan, menyiapkan makan anak dengan makanan 4 sehat 5 sempurna dapat mengurangi resiko terjadinya stunting pada anak di Posyandu Asoka II Wilayah Pesisir Kelurahan Barombong.

Hasil penelitian Febriani (2020) mengatakan bahwa seluruh responden ibu dengan kebiasaan pemberian makan yang kurang baik terhadap balitanya, sebagian besar memiliki balita stunting yaitu sebesar $68,4 \%$. Sedangkan dari seluruh responden ibu dengan kebiasaan pemberian makan yang baik, yang memiliki balita stunting hanya sebesar 19,8\%. Ibu dengan kebiasaan pemberian makan yang kurang baik pada balitanya beresiko 8,8 kali lebih besar untuk memiliki balita stunting dibandingkan ibu dengan kebiasaan pemberian makan yang baik pada balitanya.

Perilaku ibu dalam mengasuh balitanya memiliki kaitan yang erat dengan kejadian stunting pada balita. Ibu dengan pola asuh yang baik akan cenderung memiliki anak dengan status gizi yang baik, begitu juga sebaliknya ibu dengan pola asuh gizi yang kurang cenderung memiliki anak dengan status gizi yang kurang. Aspek kunci dalam pola asuh terdiri dari perawatan dan perlindungan bagi ibu, pemberian ASI dan MP-ASI, penyiapan makanan, praktik hygiene dan sanitasi lingkungan, serta praktik kesehatan di rumah (Yesi, 2019).

Masalah kejadian stunting secara garis besar adalah pada pola asuh anak dimana ibu memberikan asuhan makanan yang tidak baik atau kekeliruan orang tua memberikan asupan makanan pada anaknya sehingga menyebabkan timbulnya penyakit kronis. Salah satu faktor ketidaktersediaan makanan yang bergizi, dan masyarakat juga biasanya mentabukan makanan yang mengandung banyak zat gizi yang baik bagi tumbuh kembang anak juga dapat menyebabkan kejadian stunting (Zian, 2018).

Pola asuh makan yang baik dicerminkan dengan semakin baiknya asupan makan yang diberikan kepada balita. Asupan makan yang dinilai secara kualitatif digambarkan melalui keragaman konsumsi pangan. Keragaman pangan mencerminkan tingkat kecukupan gizi seseorang. Rendahnya pola asuh menyebabkan buruknya status gizi balita. Jika hal ini terjadi pada masa golden age maka akan menyebabkan otak tidak dapat berkembang secara optimal dan kondisi ini sulit untuk dapat pulih kembali. (Novita, 2018)

Hasil penelitian tentang pola asuh ibu dengan kejadian stunting pada usia 24-59 bulan di wilayah Puskesmas Sekupang Kota Batam diperoleh bahwa mayoritas ibu tidak memberikan ASI Eksklusif pada anaknya dikarenakan ibu bekerja di luar rumah membantu suami mencari nafkah untuk membantu perekonomian keluarga. Rata - rata informan ibu yang memiliki anak stunting usia 24-59 bulan bekerja sebagai buruh di perusahaan dengan gaji per hari sehingga ibu terkadang tidak sempat memberikan ASI pada anaknya karena memburu waktu untuk berangkat kerja.

Pola asuh ibu dengan kejadian stunting pada anak usia 24-59 bulan berdasarkan pemberian makanan tambahan PMT-ASI diperoleh bahwa mayoritas anak yang mengalami stunting diberikan makan minum di bawah umur 6 bulan dikarenakan ibu merasa ASI tidak cukup untuk anak dan ibu sibuk bekerja. Pemberian makanan tambahan ASI sebaiknya diberikan dari anak umur 6 bulan ke atas. Pemberian makan dengan cara yang sehat, pemberian makan bergizi dan mengatur porsi yang dihabiskan akan meningkatkan status gizi anak.

Pola asuh ibu dengan kejadian stunting pada anak usia 24-59 bulan berdasarkan makanan anak diperoleh bahwa mayoritas 
ibu hanya memberikan bubur nasi saja dengan alasan cepat dan juga karena kondisi ekonomi keluarga. Menu makanan yang diberikan sebaiknya sesuai dengan kebutuhan gizi yang dibutuhkan anak dengan menu gizi seimbang disesuaikan dengan porsi zat gizi makanan yang dibutuhkan sesuai dengan umur balita bukan harus dengan jenis makanan yang harganya mahal.

Pola asuh ibu dengan kejadian stunting pada anak usia 24-59 bulan berdasarkan orang yang menyiapkan makanan anak diperoleh bahwa mayoritas ibu menyiapkan makanan anak sebelum berangkat kerja. Menu makanan yang diberikan ibu berupa bubur nasi atau makanan siap saji yang dibeli sehingga tidak mencukupi kebutuhan gizi yang dibutuhkan anak. Berdasarkan suasana makan anak diperoleh bahwa mayoritas ibu sudah membuat suasana menyenangkan saat anak makan tetapi anak tetap saja sulit makan dan lebih memilih jajan di warung.

Pola asuh ibu dengan kejadian stunting pada anak usia 24-59 bulan menurut informan petugas gizi dan petugas posyandu di wilayah puskemas Kelurahan Sekupang bahwa anak yang mengalami stunting mayoritas disebabkan pola makan anak yang kurang baik, anak sulit makan, tidak mendapat ASI eksklusif dan memberikan PMT-ASI pada anak umur kurang dari 6 bulan dan imunisasi anak yang tidak lengkap. Tenaga kesehatan telah melakukan penanganan stunting dengan memberikan penyuluhan tentang pemberian makan dengan gizi seimbang bagi anak, memberikan makanan tambahan berupa biskuit yang ada di puskesmas untuk anak yang mengalami stunting dan mengadakan kunjungan imunisasi ke rumah-rumah tiap bulan untuk mengetahui pertumbuhan dan perkembangan berat badan anak.

Peneliti juga menemukan beberapa fakta di lapangan dari informan terkait dengan pola pemberian makan balita stunting sehingga peneliti merasa perlu adanya konsultasi dan pendampingan gizi dari tenaga kesehatan di wilayah kerja
Puskesmas Kelurahan Sekupang Kota Batam khususnya ibu yang mempunyai anak stunting.

Menurut asumsi peneliti, setiap ibu perlu belajar menyediakan berbagai jenis makanan dan tidak harus makanan yang mahal tetapi makanan yang mungandung zat gizi yang cukup. Pola konsumsi balita yang tidak terkontrol seperti kebiasaan jajan yang berlebihan harus diwaspadai oleh orang tua. Jadwal pemberian makan yang ideal adalah tiga kali makanan utama dan dua kali makanan selingan yang bergizi untuk melengkapi komposisi gizi seimbang dalam sehari yang belum terpenuhi pada makanan utama.

\section{Pola Asuh Ibu Berdasarkan Asuhan Perawatan Dasar Anak Dengan Kejadian Stunting Pada Anak Usia 24-59 Bulan}

Hasil penelitian berdasarkan perawatan dasar anak, diperoleh bahwa mayoritas imunisasi dasar anak sebelum usia 1 tahun tidak lengkap dikarenakan anak sering sakit. Apabila anak sakit, ibu membawa anak berobat ke puskesmas karena puskesmas merupakan fasilitas pelayanan kesehatan yang paling dekat dengan rumah, yang mengasuh anak pada saat ibu bekerja adalah suami dan anggota keluarga lainnya, ibu sering mengajak anak bermain tetapi karena anak sering sakit anak tidak semangat untuk bermain.

Penelitian Febriani (2020) mengatakan bahwa dari seluruh responden dengan kebiasaan pengasuhan yang kurang baik terhadap balitanya terdapat $64,7 \%$ yang memiliki balita stunting, sedangkan dari seluruh responden dengan kebiasaan pengasuhan yang baik $21,7 \%$ yang memiliki balita stunting. Ibu dengan kebiasaan pengasuhan yang kurang baik pada balitanya berisiko 6,62 kali lebih besar untuk memiliki balita stunting dibandingkan ibu dengan kebiasaan pengasuhan yang baik pada balitanya.

Ibu yang merawat anaknya sendiri lebih sehat dibandingkan dengan ibu yang menitip anaknya kepada orang lain. Pemberian imunisasi dasar yang lengkap 
harus didapat anak sebelum anak berusia 1 tahun melalui kunjungan posyandu. Jika anak sakit, ibu membawa anak berobat langsung ke puskesmas dan tidak membiarkan anak di rumah dalam keadaan sakit (Soetjiningsih, 2015).

Hal ini sesuai dengan penelitian mengenai positive deviance pada keluarga miskin yang mengungkapkan bahwa asuhan psikososial berupa keterikatan antara ibu dan anak menjadi faktor penting dalam tumbuh kembang anak. Kondisi psikososial yang buruk dapat mempengaruhi pemanfaatan zat gizi dalam tubuh, sebaliknya hormon pertumbuhan dirangsang kondisi psikososial yang baik. Secara tidak langsung asuhan psikososial berkaitan dengan asuhan gizi dan kesehatan yang berpengaruh positif pada status gizi, tumbuh dan kembang anak (Febriani, 2020).

Hasil penelitian bahwa pola asuh ibu dengan kejadian stunting pada anak usia 24-59 bulan berdasarkan asuhan perawatan dasar anak, mayoritas anak diasuh oleh ibu sendiri dan dibantu suami atau anggota keluarga lain. Ibu bekerja mempunyai aktivitas di luar rumah untuk membantu perekonomian keluarga sehingga kurang dalam melakukan perawatan dasar anak. Ibu bekerja mempunyai aktivitas yang lebih banyak di luar rumah sehingga kurang dalam melakukan perawatan dasar anak.

Pola asuh ibu dengan kejadian stunting pada anak usia 24-59 bulan berdasarkan asuhan perawatan dasar anak dengan pemberian imunisasi dasar bahwa mayoritas anak tidak mendapatkan imunisasi yang lengkap sampai umur 1 tahun dikarenakan anak sering sakit dan ibu tidak mempunyai waktu untuk membawa anak imunisasi ke posyandu.

Petugas posyandu selalu memberikan penyuluhan tentang asuhan perawatan dasar yang dibutuhkan anak dalam penanganan stunting pada anak usia 24-59 bulan serta ibu diberikan kesempatan untuk bertanya tentang masalah yang dihadapi ibu dalam memberikan asuhan perawatan dasar pada anak. Petugas posyandu juga menyarankan kepada ibu untuk membawa anak ke puskesmas apabila anak sakit

Pola pengasuhan yang baik merupakan gambaran adanya interaksi positif anak dengan pengasuh utama yang berperan dalam perkembangan emosi dan psikologis anak sehingga menciptakan tumbuh kembang anak yang normal. Peran orang tua sedini mungkin akan menjalin rasa aman pada anaknya. Hal tersebut diwujudkan dengan kontak fisik dan psikologis sejak anak lahir hingga dalam proses tumbuh kembangnya. Kurangnya kasih sayang orang tua di tahun-tahun pertama berdampak negatif pada tumbuh kembang anak baik fisik, mental, maupun sosial emosi. Kasih sayang orang tua akan menciptakan ikatan yang erat (bonding) dan kepercayaan dasar (basic trust).

\section{Pola Asuh Ibu Berdasarkan Asuhan Hygiene Dan Sanitasi Dengan Kejadian Stunting Pada Anak Usia 24-59 Bulan}

Hasil penelitian ini diperoleh bahwa mayoritas ibu menyimpan makanan di tempat tertutup dan bersih dalam lemari, anak mandi dua kali sehari yaitu pagi dan sore, ibu memotong kuku anak seminggu sekali, ibu mengganti baju anak apabila baju anak kelihatan kotor, ibu membersihkan bagian dalam dan luar rumah agar lalat tidak berkembang biak serta ibu menjaga kebersihan lingkungan dan menggunakan air galon isi ulang sebagai sumber kebutuhan keluarga dan menjaga kebersihan makanan supaya anak tidak terkena diare.

Penelitian Rahmayana (2014) mengatakan terdapat adanya hubungan antara praktik kebersihan/higyene dengan kejadian stunting pada anak usia 24-59 bulan di Posyandu Asoka II Wilayah Pesisir Kelurahan Barombong. Hasil penelitian diperoleh bahwa pada kategori kebersihan/higyene menunjukkan $61,9 \%$ tinggi anak normal.

Selanjutnya penelitian Ana (2019) mengatakan bahwa kebersihan diri yang menyangkut kebersihan tubuh, kebersihan makanan dan lingkungan berperan dalam 
pemeliharaan kesehatan anak serta mencegah penyakit infeksi yang dapat mempengaruhi status gizi anak. Pada umumnya kebiasaan kebersihan ibu atau pengasuh lainnya masih belum sesuai dengan prinsip-prinsip hygiene dan sanitasi lingkungan, hal ini dapat dilihat pada saat observasi langsung ke rumah responden.

Penelitian Febriani (2020) mengatakan bahwa seluruh responden ibu dengan kebiasaan kebersihan yang kurang baik terhadap balitanya $71,4 \%$ memiliki balita stunting sedangkan dari seluruh responden ibu dengan kebiasaan kebersihan yang baik $25,8 \%$ memiliki balita stunting. Ibu dengan kebiasaan kebersihan yang kurang baik pada balitanya memiliki peluang 7,19 kali lebih besar untuk memiliki balita stunting dibandingkan ibu dengan kebiasaan kebersihan yang baik pada balitanya.

Pola hidup sehat dan bersih harus diterapkan ibu dalam keluarga walaupun ibu mempunyai kesibukan di luar rumah tetapi ibu harus menyediakan waktu untuk menjaga kebersihan lingkungan tempat anak bermain dan kebersihan peralatan yang digunakan anak (Soetjiningsih, 2015).

Hasil penelitian menunjukkan pola asuh ibu dengan kejadian stunting pada anak usia 24-59 bulan berdasarkan asuhan higiene dan sanitasi di wilayah kerja Puskesmas Sekupang Kota Batam mayoritas menyimpan makanan di tempat tertutup dan bersih dalam lemari sehingga terjaga kebersihan makanan dan terhindar dari kotoran atau lalat sebagai penular penyakit. Kebersihan diri maupun lingkungan berperan penting dalam tumbuh kembang anak. Kebersihan tubuh, makanan dan lingkungan berperan besar dalam pemeliharaan kesehatan yang akan mencegah penyakit-penyakit infeksi sebagai faktor penyebab turunnya status gizi anaknya.

Pola asuh ibu dengan kejadian stunting pada anak usia 24-59 bulan menurut informan ibu yang memiliki anak usia 2459 bulan berdasarkan asuhan higiene dan sanitasi, mayoritas anak mandi dua kali sehari yaitu pagi dan sore. Kebiasaan kebersihan harus sesuai dengan syarat kesehatan dalam menjaga kesehatan tubuh dengan mandi dua kali sehari, rambut, tangan, kaki dan pakaian harus bersih, menggosok gigi, menjaga kebersihan diri dan lingkungan. Kebersihan diri yang tidak baik akan memudahkan terjadinya penyakit infeksi saluran pencernaan seperti diare dan cacingan. Mayoritas anak potong kuku seminggu sekali. Dengan ibu memotong kuku anak semingga sekali sehingga anak dapat terhindar dari penyakit yang disebabkan oleh kuku yang panjang pada anak. Ibu menganti baju anak apabila baju anak kelihatan kotor. Pakaian yang kotor pada anak dapat menyebabkan anak mengalami penyakit yang disebabkan oleh lingkungan yang kurang bersih. Untuk memenuhi kebutuhan air minum keluarga sebagian informan menggunaka air galon isi ulang serta mayoritas informan menjaga kebersihan lingkungannya.

Pola asuh ibu dengan kejadian stunting pada anak usia 24-59 bulan berdasarkan asuhan higiene dan sanitasi menurut informan petugas gizi dan petugas posyandu di Puskesmas Kelurahan Sekupang bahwa asuhan higiene dan sanitasi dapat dikategorikan bersih. Penyebab anak mengalami stunting dikarenakan mayoritas asupan makan yang kurang. Tenaga kesehatan telah memberikan penyuluhan tentang hygiene dan sanitasi yang baik. Petugas kesehatan melakukan kunjungan rumah untuk melihat kebersihan anak yakni tempat penyimpanan makan anak, cara memandikan anak, ibu memotong kuku anak sekali seminggu, ibu menganti pakaian anak apabila kotor dan membersihkan bagian dalam dan luar rumah agar lalat tidak berkembang biak.

\section{KESIMPULAN}

Pola asuh ibu berdasarkan asuhan pemberian makan, mayoritas ibu tidak memberikan ASI Eksklusif pada anaknya, anak sudah diberikan makan dan minum di bawah umur 6 bulan, ibu sudah memberikan anak sarapan pagi tetapi anak 
sulit makan dikarenakan anak tidak selera dan lebih suka jajan di warung, ibu menyiapkan sendiri makanan anaknya dan memberikan anak makan hanya bubur nasi saja. Pola asuh ibu berdasarkan asuhan perawatan dasar anak, mayoritas ibu mengasuh anak sendiri, imunisasi dasar pada anak sebelum usia 1 tahun tidak lengkap dikarenakan anak sering sakit, ibu membawa anak berobat ke puskesmas, yang menjaga anak kalau ibu bekerja adalah suami atau keluarga lain, ibu sering mengajak anak untuk bermain tetapi anak tidak bersemangat karena sering sakit. Pola asuh ibu berdasarkan asuhan hygiene dan sanitasi, mayoritas ibu menyimpan makanan di tempat tertutup dan bersih dalam lemari, anak mandi dua kali sehari, anak potong kuku seminggu sekali, ibu menganti baju anak apabila baju anak kelihatan kotor, ibu membersihkan bagian dalam dan luar rumah agar lalat tidak berkembang biak serta ibu memakai air galon dalam mememuhi kebutuhan air minum keluarga.

\section{UCAPAN TERIMAKASIH}

Dalam penelitian ini, peneliti banyak mendapatkan bantuan dari berbagai pihak. Sehubungan dengan hal tersebut peneliti mengucapkan terima kasih kepada Kepala Puskesmas dan Para Pembimbing yang sudah bersedia membantu peneliti.

\section{DAFTAR PUSTAKA}

Ana Samiatul Milah, Ade Zaqiah, (2019). Penanggulangan Stunting Dan Pemberian Asupan Nutrisi Dengan Kejadian Status Gizi Pada Anak Usia 0-5 Tahun di Desa Pawindan Kabupaten Ciamis Tahun 2019. JMPH (Journal of Midwifery and Public Health). Volume 2 No. 1 | Mei 2020 ISSN: 2685-4007. jurnal.unigal.ac.id > index.php > article > download. Diakses pada tanggal 2 September 2020.
Arikunto, S. (2013). Prosedur Penelitian Suatu Pendekatan Praktik. Jakarta: PT. Rineka Cipta.

Asnuddin, Hasrul, (2019). Analisis Pola Asuh Keluarga Terhadap Status Gizi Balita. Jurnal Kebidanan dan Keperawatan Aisyiyah, 15 (1), 2019, $37-45$. ejournal.unisayogya.ac.id , jkk , article > view. Diakses pada tanggal 2 September 2020.

Bahar, Z., (2012). PD dan Karakteristik Individu yang Memberikannya, Rineka Cipta, Jakarta.

Bella,Febriani Dwi, Nur Alam Fajar, Misnaniarti, (2020). Hubungan antara Pola Asuh Keluarga dengan Kejadian Balita Stunting pada Keluarga Miskin di Palembang. Jurnal Epidemiologi Kesehatan Komunitas. 5 (1), 2020, 15-22. ejournal2.undip.ac.id > jekk > article > download. Diakses pada tanggal 20 Agustus 2020.

Husaini, (2012). Bayi Berhak Atas Pola ASuh Yang Baik, Rineka Cipta, Jakarta

$\begin{array}{crr}\text { Kementerian } & \text { Kesehatan } & \text { Republik } \\ \text { Indonesia, } & \text { (2017). } & \text { Desa, } \\ \text { Pembangunan daerah } & \text { Teringgal, } \\ \text { dan Transmigrasi. Buku } & \text { Saku Desa } \\ \text { dalam Penanganan } & \text { Stunting. } \\ \text { Jakarta. } & \end{array}$

Kementerian Kesehatan RI. (2018). Ini Penyebab Stunting Pada Anak. Jakarta.

Kementerian Kesehatan RI. (2018). Hasil Utama Riskesdas 2018. Jakarta.

$\begin{array}{llr}\text { Kementerian } & \text { Kesehatan } & \text { Republik } \\ \text { Indonesia, } & (2020) . & \text { Peraturan } \\ \text { Menteri } & \text { Kesehatan } & \text { Republik } \\ \text { Indonesia } & \text { Nomor 2 } & \text { Tahun 2020 } \\ \text { Tentang } & \text { Standar Antropometri } \\ \text { Anak. } & \text { Tersedia } & \text { dari } \\ \text { hukor.kemkes.go.id }>\text { uploads , } \\ \text { produk_hukum > PMK. Diakses } \\ \text { pada tanggal 18 Mei 2020. }\end{array}$


Moelong, (2016). Metode Penelitian Kualitatif (Edisi Revisi). Bandung: Remaja Rosda Karya.

Notoadmodjo, S. (2012). Metodologi Penelitian Kesehatan. Jakarta: Rineka Cipta

Nova Dwi Yanti, Feni Betriana \& Imelda Rahmayunia Kartika, (2020). Faktor Penyebab Stunting Pada Anak: Tinjauan Literatur. REAL in Nursing Journal (RNJ) Research of Education and Art Link in Nursing Journal. ojs.fdk.ac.id > index.php > Nursing , article , download. Diakses pada tanggal 5 September 2020

Novita Nining Widyaningsih, Kusnandar, Sapja Anantanyu,(2018). Keragaman Pangan, Pola Asuh Makan Dan Kejadian Stunting Pada Balita Usia 24-59 Bulan. Jurnal Gizi Indonesia (The Indonesian Journal of Nutrition). Vol. 7, No. 1, Desember $2018 \quad$ (22-29). www.researchgate.net > publication > 330004795_Keraga. Diakses pada tanggal 5 September 2020

Puskesmas Sekupang Kota Batam, (2020). Laporan Puskesmas Sekupang Kota Batam Tahun 2020

Rahmayana, Irviani A. Ibrahim, Dwi Santy Damayati, (2014). Hubungan Pola Asuh Ibu Dengan Kejadian Stunting Anak Usia 24-59 Bulan di Posyandu Asoka II Wilayah Pesisir Kelurahan Barombong Kecamatan Tamalate Kota Makassar Tahun 2014. journal.uin-alauddin.ac.id > article > download. Diakses pada tanggal 12 September 2020

Risani Rambu Podu Loya, Nuryanto, (2017). Pola Asuh Pemberian Makan Pada Balita Stunting Usia 612 Bulan di Kabupaten Sumba Tengah Nusa Tenggara Timur. media.neliti.com, media, publications > 200664-pola. Diakses pada tanggal 2 September 2020
Soetjiningsih, (2015). Tumbuh Kembang Anak. Jakarta : EGC

Sugiyono, (2016). Metode Penelitian Kuantitatif Kualitataif dan Kombinasi (Mixed Methods). Bandung: Alfabeta

Suharsih, B., (2018). Panduan Sehat Ibu Menyusui, Gramedia, Jakarta

Supariasa, IDN, dkk. (2016). Penilaian Status Gizi. Jakarta: Penerbit Buku Kedokteran EGC

Supartini Tri, Lilis Lestari, Winarianti, (2019). Hubungan Pemenuhan Kebutuhan Asuh Ibu Terhadap Status Stunting Pada Balita Usia 15 Tahun di Puskesmas X Kabupaten Kubu Raya Pontianak. jurnal.untan.ac.id , index.php , article , download. Diakses pada tanggal 5 September 2020

Syahrul Sarea. (2014). Pengertian Pola Asuh Anak Dalam Keluarga. wawasan pendidikan. Jakarta

Venny Marisai Kullu, Yasnani, Hariati Lestari, (2018). Faktor-Faktor Yang Berhubungan Dengan Kejadian Stunting Pada Balita Usia 24-59 Bulan di Desa Wawatu Kecamatan Moramo Utara Kabupaten Konawe Selatan Tahun 2017. Jimkesmas. Jurnal Ilmiah Mahasiswa Kesehatan Masyarakat. VOL. 3/NO.2/ April 2018; ISSN 2502-731X. ojs.uho.ac.id > index.php , JIMKESMAS, article, view. Diakses pada tanggal 5 Agustus 2020

WHO, World Bank (2017). Levels and trends in child malnutrition. http://www.who.int/nutgrowthdb/jm e_unicef_who_wb.pdf - Diakses Nopember 2017.

Widaninggar, dkk. (2013). Мепијu Gizi Baik yang Merata di Pedesaan dan di Kota. Yogyakarta : Gajah Mada Univesity Press

Yesi Nurmalasari., dkk. (2019). Status Gizi Ibu Hamil Dapat Menyebabkan 
Volume 5, Nomor 1, April 2021

ISSN 2623-1581 (Online)

ISSN 2623-1573 (Print)

Kejadian Stunting Pada Balita.

Jurnal Kebidanan.

Zian. (2018). Masalah Pola Asuh Ibu Pada

Kejadian Stunting. Jurnal

Universitas Muhammadiyah Palu. 